\title{
ANALYSIS OF RESISTANCE TO ANTIMYCOBACTERIAL DRUGS AMONG MTBC STRAINS ISOLATED FROM CATTLE IN POLAND AS A THREAT TO HUMAN HEALTH
}

\section{ANALIZA OPORNOŚCI NA LEKI PRZECIWPRĄTKOWE WŚRÓD SZCZEPÓW MTBC IZOLOWANYCH OD BYDŁA W POLSCE JAKO ZAGROŻENIE DLA ZDROWIA LUDZI}

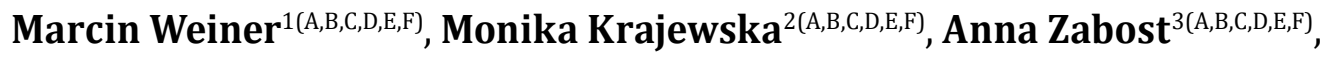 \\ Ewa Augustynowicz-Kopeć ${ }^{3(\mathrm{~A}, \mathrm{~B}, \mathrm{C}, \mathrm{D}, \mathrm{E}, \mathrm{F})}$, Krzysztof Szulowski ${ }^{2(\mathrm{~A}, \mathrm{~B}, \mathrm{C}, \mathrm{D}, \mathrm{E}, \mathrm{F})}$ \\ ${ }^{1}$ Pope John Paul II State School of Higher Education in Biała Podlaska, Poland \\ ${ }^{2}$ National Veterinary Research Institute in Puławy, Poland \\ ${ }^{3}$ National Tuberculosis and Lung Diseases Research Institute in Warsaw, Poland
}

\begin{abstract}
Authors' contribution Wkład autorów:

A. Study design/planning zaplanowanie badań B. Data collection/entry zebranie danych C. Data analysis/statistics dane - analiza i statystyki D. Data interpretation interpretacja danych E. Preparation of manuscript przygotowanie artykułu F. Literature analysis/search wyszukiwanie i analiza literatury G. Funds collection zebranie funduszy
\end{abstract}

Tables: 0

Figures: 2

References: 27

Submitted: 2016 Feb 23

Accepted: 2016 Apr 6

\section{Summary}

Background. Tuberculosis is a highly contagious disease affecting humans and animals. It is caused by mycobacteria that are part of the Mycobacterium tuberculosis complex (MTBC). The etiological agent causing bovine tuberculosis is mycobacteria bovis: Mycobacterium bovis and Mycobacterium caprae. According to the World Health Organization bovine tuberculosis is classified as direct zoonosis.

Material and methods. The study material consisted of 129 MTBC strains isolated from Polish cattle, which were microbiologically analyzed. The resistance phenotype was tested for first-line anti-tuberculosis drugs used in the treatment of tuberculosis in humans. The drugs included streptomycin, isoniazid, rifampicin, ethambutol, and pyrazinamide. The MTBC strains tested in this study were isolated from cattle tissue post mortem so that the determination of drug resistance could meet only the epidemiological criterion.

Results. Polish strains of mycobacteria bovis have not acquired environmental resistance despite the huge dynamics of changes in the phenotype of mycobacterial tuberculosis resistance. Strains classified as $M$. bovis are characterized by natural resistance to PZA, which is typical of this species.

Conclusions. Drug resistance imposes the use of additional drugs. Drugs that are less effective than the basic drugs, drugs causing side effects more frequently and drugs that are much more expensive.

Keywords: drug resistance, Mycobacterium tuberculosis, bovine tuberculosis, public health, antimicrobial

\section{Streszczenie}

Wprowadzenie. Gruźlica jest wysoce zakaźną chorobą ludzi i zwierząt, którą powodują prątki wchodzące w skład kompleksu Mycobacterium tuberculosis (MTBC). Czynnikiem etiologicznym gruźlicy bydlęcej są prątki bydlęce: Mycobacterium bovis i Mycobacterium caprae. Zgodnie z klasyfikacją Światowej Organizacji Zdrowia, gruźlica typu bydlęcego zaliczana jest do zoonoz bezpośrednich.

Materiał i metody. W pracy poddano analizie mikrobiologicznej 129 szczepów MTBC wyizolowanych od bydła w Polsce. Fenotyp oporności zbadano pod kątem leków przeciwprątkowych pierwszej linii stosowanych w leczeniu gruźlicy u ludzi: streptomycyny, izoniazydu, rifampicyny, etambutolu i pyrazynamidu. Szczepy MTBC badane w niniejszej pracy wyizolowano z tkanek bydła pobranych post mortem, tak że oznaczenie lekooporności w tym zadaniu spełniło jedynie kryterium epidemiologiczne.

Wyniki. Polskie szczepy prątka bydlęcego nie nabyły oporności środowiskowej. Szczepy sklasyfikowane jako $M$. bovis cechują się charakterystyczną dla tego gatunku naturalną opornością na PZA.

Wnioski. Wystąpienie lekooporności zmusza do stosowania leków dodatkowych, mniej skutecznych niż leki podstawowe i powodujących częściej objawy uboczne, a jednocześnie znacznie droższych.

Słowa kluczowe: lekooporność, Mycobacterium tuberculosis complex, gruźlica bydlęca, zdrowie publiczne, leki przeciwprątkowe

Weiner M, Krajewska M, Zabost A, Augustynowicz-Kopeć E, Szulowski K. Analysis of resistance to antimycobacterial drugs among MTBC strains isolated from cattle in Poland as a threat to human health. Health Prob Civil. 2020; 14(1): 24-28. https://doi.org/10.5114/hpc.2020.92423

Address for correspondence / Adres korespondencyjny: Marcin Weiner, Pope John Paul II State School of Higher Education, Sidorska 95/97, 21-500 Biala Podlaska, Poland, e-mail: mpweiner@o2.pl, phone: +48 833449900

ORCID: Marcin Weiner https://orcid.org/0000-0001-9288-0823, Monika Krajewska https://orcid.org/0000-0002-5826-2068,

Anna Zabost https://orcid.org/0000-0003-2781-9844, Ewa Augustynowicz-Kopeć https://orcid.org/0000-0001-6162-8748,

Krzysztof Szulowski https://orcid.org/0000-0001-6509-5328

Copyright: (C) Pope John Paul II State School of Higher Education in Biała Podlaska, Marcin Weiner, Monika Krajewska, Anna Zabost, Ewa Augustynowicz-Kopeć, Krzysztof Szulowski. This is an Open Access journal, all articles are distributed under the terms of the Creative Commons Attribution-NonCommercial-ShareAlike 4.0 International (CC BY-NC-SA 4.0) License (http://creativecommons.org/licenses/by-nc-sa/4.0/), allowing third parties to copy and redistribute the material in any medium or format and to remix, transform, and build upon the material, provided the original work is properly cited and states its license. 


\section{Introduction}

Tuberculosis is a highly contagious disease for humans and animals. It is caused by mycobacteria that are part of the Mycobacterium tuberculosis complex (MTBC) [1]. The etiological factor of bovine tuberculosis is mycobacteria bovis: Mycobacterium bovis and Mycobacterium caprae [2,3]. According to the World Health Organization classification, bovine tuberculosis is classified as direct zoonosis in which we can observe a direct transmission of the infectious agent from an infected vertebrate (animal) to a susceptible vertebrate, namely a human, without the participation of indirect hosts. Due to the direction of transmission of the infectious agent, bovine tuberculosis can be included in all types of zoonotic diseases. Anthropozonosis occurs when a disease is transmitted from an animal to a human, but there are also known cases of zooanthroponosis when a human is the source of the disease for an animal.

Bovine tuberculosis a disease that is eradicated by authorities. Currently, the obligation to combat this zoonotic disease is imposed primarily by the "Veterinary Inspection Act" (Ustawa o Inspekcji Weterynaryjnej), which regulates the obligations of veterinarians operating within the structures of the Inspection. The legal act referring directly to the control of infectious diseases is the "Protection of Animal Health and the Control of Infectious Animal Diseases Act” (Ustawa o ochronie zdrowia zwierząt oraz zwalczaniu chorób zakaźnych zwierząt). The most important act of Polish legislation is the Ordinance of the Minister for Agriculture and Rural Development of November 23, 2004. This act specifies methods for combating bovine tuberculosis in Poland as well as the different ways of dealing with the suspicion, detection, and termination of an outbreak of bovine tuberculosis. Poland has the status of a country that is free from this zoonotic disease despite the fact that there have been from 12 to 18 outbreaks of bovine tuberculosis each year for the last 5 years [4]. Animals that are diagnosed with tuberculosis are not treated in most cases but removed from the herd and subjected to sanitary slaughter. The only described case of tuberculosis treatment among animals in Poland concerned a 10-year-old male giraffe living in the Silesian Zoological Garden in Chorzów (Śląski Ogród Zoologiczny w Chorzowie) [5].

The first research results on pyrazinamide resistance (PZA) among MTBC strains isolated from the tissue of various animal species were published in Poland in 2013 [6]. So far, there has been no data on drug resistance to other antimycobacterial drugs among mycobacteria bovis (M. bovis and M. caprae), which are the cause of tuberculosis in animals in Poland. This study describes the phenomenon of drug resistance to streptomycin (MS), isoniazid (INH), rifampicin (RMP), and ethambutol (EMB) for the first time - S.I.R.E.

The aim of the study is the analysis of the resistance phenotype of 129 strains of MTBC to first-line antituberculosis drugs used in the treatment of tuberculosis in humans: SM, INH, RMP, EMB, and PZA.

\section{Material and methods}

The study material consisted of 129 MTBC strains isolated from the tissue of cattle. The tissue was cultured in the Stonebrink medium. The membership to MTBC was confirmed by means of an immunochromatographic test, which is used to detect the MPT64 protein fraction secreted by MTBC mycobacterial cells - Identification Test MGIT TBC ${ }^{\circledR}$. Species identification was performed using the GenoType MTBC $^{\circledR}$ test. This allowed us to classify 98 strains as Mycobacterium bovis and 31 strains as Mycobacterium caprae.

Drug resistance to S.I.R.E. was determined utilizing Bactec MIGIT 960 and Middlebrook 7H9 liquid medium with a concentration limit SM $1.0 \mu \mathrm{g} / \mathrm{ml}$, INH $0.1 \mu \mathrm{g} / \mathrm{ml}$, RMP $1.0 \mu \mathrm{g} / \mathrm{ml}$ and EMB $5.0 \mu \mathrm{g} / \mathrm{ml}$. The apparatus determines sensitivity by comparing fluorescence analysis in test tubes containing drugs to fluorescence in control test tubes.

Drug resistance to PZA was determined in the Bactec 460-Tb isotopic system [7] and Middlebrook 7H12 liquid medium containing palmitic acid [14C] with $\mathrm{pH}$ in the range 5.9-6.0 and PZA concentration limit 100 $\mu \mathrm{g} / \mathrm{ml}$. Growing mycobacteria metabolized the substrate contained in the medium to $14 \mathrm{CO}_{2}$. The amount of the produced $14 \mathrm{CO}_{2}$ was directly proportional to the intensity of the mycobacterial growth in the medium. The addition of PZA to the medium inhibited the growth of $M$. caprae. This phenomenon was reflected in the decrease in the amount of $14 \mathrm{CO}_{2}$ compared to the control strain, in which the amount of $14 \mathrm{CO}_{2}$ and the growth index increased systematically. In the case of resistant strains, little or no difference was observed in the growth index between the control and the tested strain [8].

\section{Results}

In the group of 98 mycobacteria bovis strains, which were identified as $M$. bovis, all the strains were susceptible to 4 primary antimycobacterial drugs: INH, RMP, SM, and EMB as well as resistant to PZA (Figure 1). 


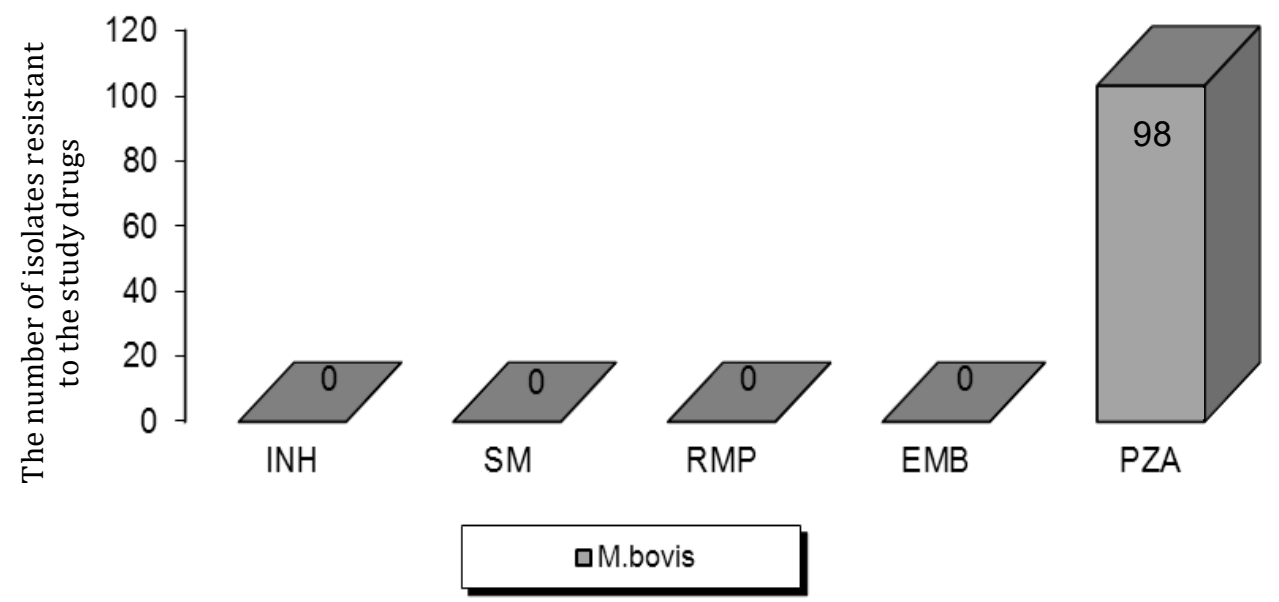

Figure 1. The results of the drug resistance analysis for M. bovis strains to S.I.R.E. and PZA

In the group of 31 mycobacteria bovis strains identified as M. caprae, all the strains exhibited sensitivity to PZA and 4 primary antimycobacterial drugs: INH, RMP, SM, and EMB (Figure 2).

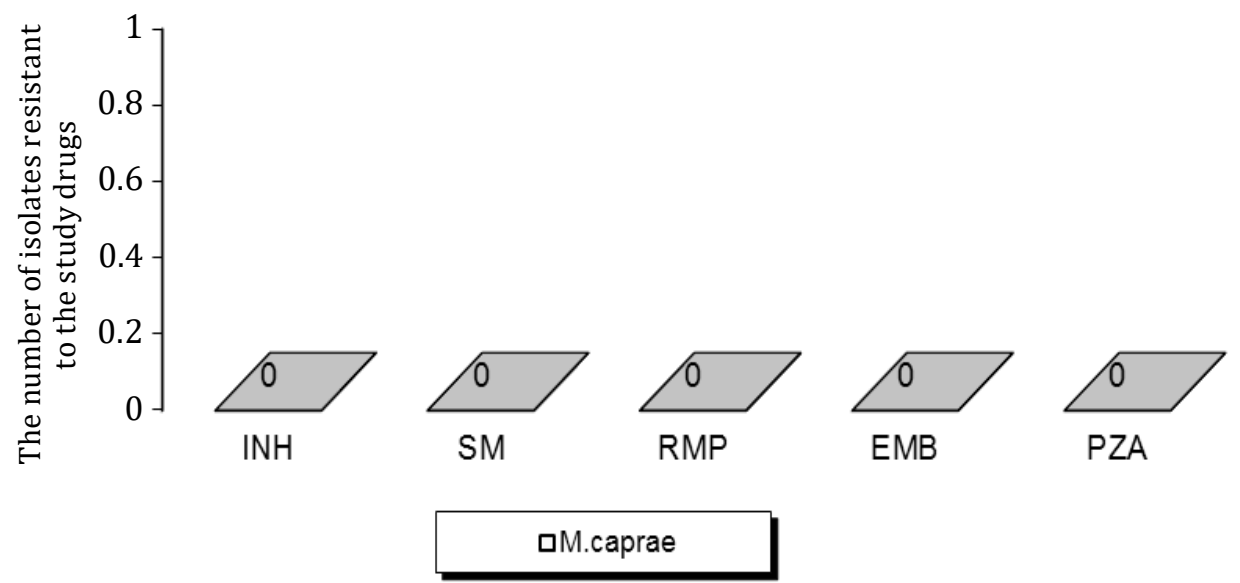

Figure 2. The results of the drug resistance analysis for M. caprae strains to S.I.R.E. and PZA

\section{Discussion}

The incidence of bovine tuberculosis among Europeans tends to increase compared to previous years. Therefore, determining the resistance phenotype in MTBC strains isolated from animals to first-line antituberculosis drugs used in the treatment of tuberculosis in humans seems to be justified in the aspect of public health. The data from 2014 concerning bovine tuberculosis in humans and included in the 2015 EFSA Report came from 27 EU Member States (except for France) as well as Iceland, Norway, and Switzerland. 134 cases of disease caused by $M$. bovis were confirmed. The highest incidence was reported in Germany - 45 cases, Great Britain - 29 cases and Spain - 25 cases. Other cases were found in Belgium - 12, the Netherlands - 9, Ireland - 6, Italy - 6, Switzerland - 2, and isolated cases in Austria and Finland [9]. The World Health Organization (WHO) estimates that in countries where Tuberculosis Programs are inadequately monitored, $1 \%$ of human cases is caused by mycobacteria bovis. To date, two cases of tuberculosis in humans caused by mycobacteria bovis have been described in Poland. The patients came from the southern region of Poland [10]. According to the EFSA report, the main source of M. bovis infections in humans is incorrectly pasteurized milk from infected cows.

The largest reservoir of mycobacteria bovis in Poland is sick cattle. The reservoir can also include wild animals living in close proximity to farms [11]. The badger population in Great Britain is the largest reservoir of mycobacteria bovis [12]. In Spain, however, the largest reservoir of mycobacteria bovis is the wild boar [13]. The transmission of mycobacteria bovis can occur on joint pastures. It can also be the result of a bite but this happens less frequently. There was a reported case from around Cornwall (France) where a dog owner was bitten by a badger and fell ill. The owner was diagnosed with tuberculosis caused by M. bovis. Four months later, 
her dog displayed respiratory symptoms, and a mycobacterial strain with the same molecular pattern as the in the case of the owner was isolated from the dog's tracheal washings [14].

Mycobacteria bovis can also cause tuberculosis in other livestock species. Mycobacteria bovis shows high virulence in natural conditions in goats [15] pigs [16,17], sheep [18] and cats [19], lower in horses [20] and dogs [21]. Cattle are not very sensitive to mycobacteria, but there are known cases of M. tuberculosis infection in cattle [22].

Multidirectional tuberculosis transmission indicates the need for close cooperation between veterinary services and human medicine (sanitary and epidemiological supervision services). In the event of tuberculosis in cattle, District Veterinary Officers should take into account the transmission of the disease to humans and notify the District Sanitary and Epidemiological Station as indicated by the regulation which is in force in Poland.

The most important component of modern tuberculosis control programs is the early detection of the disease $[23,24]$ and properly selected TB treatment [25]. The last breakthrough in TB treatment was the discovery of RMP in 1965 - half a century ago. The biggest problem in implementing tuberculosis control programs around the world is the phenomenon of mycobacterial tuberculosis resistance and the lack of new drugs [26]. Drugresistant tuberculosis, especially its varieties MDR-TB (multidrug-resistant) and XDR-TB (extensively drugresistant), is a highly fatal disease. In the case of people infected with HIV, the mortality of drug-resistant TB is $90 \%$.

Drug resistance imposes the use of additional drugs. Drugs that are less effective than the basic drugs, drugs causing side effects more frequently and drugs that are much more expensive. The treatment of drug-resistant TB is 100 times more costly than treatment involving the basic drugs [27].

\section{Conclusions}

The MTBC strains were isolated from cattle tissue post mortem, and the determination of drug resistance met only the epidemiological criterion. The obtained results showed that the Polish strains of mycobacteria bovis isolated from the animals have not acquired environmental resistance. The strains classified as $M$. bovis are characterized by natural resistance to PZA, which is typical of this species.

\section{References:}

1. Aranaz A, Cousins D, Mateos A, Domínguez L. Elevation of Mycobacterium tuberculosis subsp. caprae Aranaz et al. 1999 to species rank as Mycobacterium caprae comb. nov., sp. nov. Int. J Syst. Evol. Microbiol. 2003; 53(6): 1785-1789. https://doi.org/10.1099/ijs.0.02532-0

2. Bailey SS, Crawshaw TR, Smith NH, Palgrave CJ. Mycobacterium bovis infection in domestic pigs in Great Britain. Vet. J. 2013; 198(2): 391-397. https://doi.org/10.1016/j.tvjl.2013.08.035

3. Beltrán-Beck B, Ballestros C, Vicente J, de la Fuente J, Gortázar C. Progress in oral vaccination against tuberculosis in its main wildlife reservoir in Iberia, the Eurasian wild boar. Vet. Med. Int. 2012; 2012: 978501. https://doi.org/10.1155/2012/978501

4. Campbell TA, Long DB, Bazan LR, Thomsen BV, Robbe-Austerman S, Davey RB, etal. Absence of Mycobacterium bovis in feral swine (Sus scrofa) from the southern Texas border region. J. Wildl. Dis. 2011; 47(4): $974-978$. https://doi.org/10.7589/0090-3558-47.4.974

5. Corner LA. The role of wild animal populations in the epidemiology of tuberculosis in domestic animals: how to assess the risk. Vet. Microbiol. 2006; 112(2-4): 303-312. https://doi.org/10.1016/j.vetmic.2005.11.015

6. Crawshaw T, Daniel R, Clifton-Hadley R, Clark J, Evans H, Rolfe S, et al. TB in goats caused by Mycobacterium bovis. Vet. Rec. 2008; 163: 127. https://doi.org/10.1136/vr.163.4.127

7. Gallagher J, Clifton-Hadley RS. Tuberculosis in badgers; a review of the disease and its significance for other animals. Res. Vet. Sci. 2000; 69(3): 203-217. https://doi.org/10.1053/rvsc.2000.0422

8. Iseman MD, Madsen LA. Drug-resistant tuberculosis. Clin. Chest Med. 1989; 10: 341-353.

9. Jagielski T, Augustynowicz-Kopeć E, Zwolska Z. [Genotyping of Mycobacterium tuberculosis. An overview of the major research techniques (part I)]. Pol. Merk. Lek. 2010; 29(171): 206-211 (in Polish).

10. Karlson AG, Lessel EF. Mycobacterium bovis nom. Nov. Int. J. Syst. Bacteriol. 1970; 20: 273-282. https://doi.org/10.1099/00207713-20-3-273

11. Krajewska M, Kozińska M, Zwolska Z, Lipiec M, Augustynowicz-Kopeć E, Szulowski K. Human as a source of tuberculosis for cattle. First evidence of transmission in Poland. Vet. Microbiol. 2012; 159(1-2): $269-271$. https://doi.org/10.1016/j.vetmic.2012.04.001

12. Krajewska M, Napiórkowska A, Augustynowicz-Kopeć E. [Pyrazinamide resistance among Mycobacterium bovis strains isolated from animals in Poland]. Życie Wet. 2013; 88(7): 575-577 (in Polish). 
13. Krajewska M, Załuski M. [Tuberculosis in giraffe - attempt to treatment]. Paper presented at: Scientific and Training Conference "Pharmacological and environmental aspects of rational therapy"; 2012 Dec 11-14; Krynica Zdrój, Poland (in Polish).

14. Krajewska M. [Characterization of Mycobacterium bovis strains isolated from animals in Poland] [dissertation]. Puławy: PIWet-PIB Puławy; 2015 (in Polish).

15. Michałowska-Mitczuk D. [Pharmacotherapy of tuberculosis]. Postępy Farmakoterapii. 2009; 65: 51-58 (in Polish).

16. Monies RJ, Cranwell MP, Palmer N, Inwald J, Hewinson RG, Rule B. Bovine tuberculosis in domestic cats. Vet. Rec. 2000; 146: 407-408. https://doi.org/10.1136/vr.146.14.407

17. Monreal L, Segura D, Segalés J, Garrido JM, Prades M. Diagnosis of Mycobacterium bovis infection in a mare. Vet. Rec. 2001; 149: 712-714. https://doi.org/10.1136/vr.149.23.712

18. Muñoz Mendoza M, Juan LD, Menéndez S, Ocampo A, Mourelo J, Sáez JL, et al. Tuberculosis due to Mycobacterium bovis and Mycobacterium caprae in sheep. Vet. J. 2012; 191(2): 267-269.

https://doi.org/10.1016/j.tvjl.2011.05.006

19. Napiórkowska A, Zwolska Z, Augustynowicz-Kopeć E. [Resistance to pyrazinamide among Mycobacterium tuberculosis strains isolated from patients from the Mazovian Voivodeship in 2008-2010 years]. Post. N. Med. 2011; 24, 819-823 (in Polish).

20. Olesiejuk R, Maciak L, Milanowski J. [The importance of the Bactec radiometric method for the introduction of anti-mycobacterium treatment]. Pneumol. Alergol. Pol. 2002; 70: 5-11 (in Polish).

21. Osek J, Wieczorek K. [Prevalence of zoonoses in animals and zoonotic agents in food in Europe in 2013]. Życie Wet. 2015; 90: 210-216 (in Polish).

22. Rodriguez-Campos S, Smith NH, Boniotti MB, Aranaz A. Overview and phylogeny of Mycobacterium tuberculosis complex organisms: implication for diagnostics and legislation of bovine tuberculosis. Res. Vet. Sci. 2014; 97: S5-S19. https://doi.org/10.1016/j.rvsc.2014.02.009

23. Safinowska A, Walkiewicz R, Nejman-Gryz P, Grubek-Jaworska H. [Two selected commercially based nucleic acid amlification tests for the diagnosis of tuberculosis]. Pneumonol. Alergol. Pol. 2012; 80(1): 6-12 (in Polish).

24. Shrikrishana D, de la Rua-Domenech R, Smith NH, Colloff A, Coutts I. Human and canine pulmonary Mycobacterium bovis infections in the same household: re-emergence of an old zoonotic threat? Thorax. 2009; 64: 89-91. https://doi.org/10.1136/thx.2008.106302

25. van der Burgt GM, Crawshaw T, Foster AP, Denny DJ, Schock A. Mycobacterium bovis infection in dogs. Vet. Rec. 2009; 165: 634. https://doi.org/10.1136/vr.165.21.634

26. Zientek J, Kozielski J, Augustynowicz-Kopeć E, Kozińska M, Zwolska Z. Transmission of tuberculosis among people living in border areas of Poland, Czech Republic and Slovakia. Paper presented at: II Congress of the Czech Pneumological and Phthiseological Society of CLS JEP; 2014 Sep 18-20; Olmuc, Czech Republic.

27. Zwolska Z, Augustynowicz-Kopeć E. [Drug-resistant tuberculosis]. Pol. Merk. Lek. 2011; 30: $362-366$ (in Polish). 